\title{
Evolutionary Psychology, Rape, and the Naturalistic Fallacy
}

\author{
Kong, Youjin(Oregon State University)
}

【Main Scope】 Feminist Philosophy, Philosophy of Science, Social Philosophy

【Keyword】Evolutionary Psychology, Rape, Naturalistic Fallacy, Biased Value Judgments, Adaptationism, Willful Ignorance, Socio-Cultural Context, Gender Binary/Sex Binary 【Abstract】 Feminist critics of evolutionary psychology are often accused of committing the naturalistic fallacy, that is, of inferring certain normative conclusions from evolutionary psychology's purely descriptive accounts. This article refutes the accusation of the naturalistic fallacy, by showing that evolutionary psychology's accounts of human behavior are not purely descriptive, but rather grounded on biased value judgments. A paradigmatic example is Randy Thornhill and Craig Palmer's well-known book A Natural History of Rape. I argue that at least three biased judgments are at work in Thornhill and Palmer's evolutionary psychology account of rape: (1) adaptationist approaches to evolution, (2) willful ignorance of cultural and social context, and (3) binary understanding of gender and sex. In that Thornhill and Palmer's account cannot hold without the three biased value judgments, it is not a purely factual description of rape. Therefore, feminist concerns over its normative implications do not commit the naturalistic fallacy, as it is not the case that they infer a normative conclusion from a pure description.

\section{The Naturalistic Fallacy: A Charge against Feminist Critiques of Evolutionary Psychology}

This paper aims to defend feminist critiques of evolutionary psychology. More specifically, I present a rebuttal to the argument that feminist 
philosophers of science commit the naturalistic fallacy when they critically examine evolutionary psychology's approach to gendered behavior.

Evolutionary psychology is a research approach that examines how evolutionary processes, including natural selection, have shaped the human mind.1) One of its key assumptions is that "the programs comprising the human mind were designed by natural selection to solve the adaptive problems regularly faced by our hunter-gatherer ancestors. [That is,] each evolved program exists because it produced behavior that promoted the survival and reproduction of our ancestors better than alternative programs that arose during human evolutionary history."2) In this sense, many evolutionary psychologists claim that their research programs provide some "cross-culturally universal" frameworks for understanding human behavior. Understanding the evolved mechanisms of the human mind offers ultimate explanations of human behavior, they argue, which is more systematic and fundamental than proximate explanations provided by social and cultural analyses.3)

As evolutionary psychology has become popular both within and outside academia, successfully framing itself an ultimate scientific explanation for human nature and social phenomena, ${ }^{4}$ ) it has also received considerable critical attention of philosophers.5) In particular, many feminist philosophers have

1) Barrett(2015), 1-2.

2) Tooby and Cosmides(2005), 16 .

3) Tooby and Cosmides(2005), 18.

4) A considerable number of philosophers have argued that evolutionary psychology provides useful frameworks for understanding human behavior. See, for example, Fodor(1983), Cosmides(1989), Cosmides and Tooby(2005), Carruthers(2006), 윤보석(2010), 장대익 - 이민섭(2018), to name a few.

5) As Huneman and Machery(2015) note, philosophers of biology have been the main critics of evolutionary psychology. See, for example, Buller(2015) and Richardson(2007). I will discuss other critiques from philosophers of biology as I proceed through my argument. For critical analyses of evolutionary psychology developed by philosophers in South Korea, see 천현득(2009), 김요한(2019), 조현진(2019). 
raised concerns over "the social and political implications of research that stays consistent with and reinforces dangerous gender stereotypes."6) Evolutionary psychology research that claims to provide universal accounts of, for example, how girls and boys come to prefer feminine and masculine toys respectively, ${ }^{7)}$ why men have a better sense of direction than women, ${ }^{8)}$ and how rape is an evolved adaptation ${ }^{9}$ ) may perpetuate gender biases and discrimination against women. This is a valid concern, especially in societies such as South Korea where there are increasing discussions on gender equality. The accounts that there are "natural," "scientific" roots of gender stereotypes and power inequalities between women and men can hinder equity. For instance, the supposed evolutionary bases of rape could send the wrong message that the crime is excusable, which undermines feminist efforts to eliminate sexual violence such as the worldwide \#MeToo movement and women's rallies in South Korea to protest against spy cameras (molka).10)

In response to the criticism, evolutionary psychologists tend to argue that feminist critics commit the naturalistic fallacy.11) The term "naturalistic fallacy," which originated from David Hume and G. E. Moore,12) indicates

6) Fehr(2012), 55. The special issue published by Hypatia: A Journal of Feminist Philosophy in Winter 2012 (Meyers ed. 2012) contains important feminist critiques of evolutionary psychology, which I will discuss in this article. Other useful analyses from feminist philosophers include O'Donavan (2013) and Meynell(2021). It is worth noting that, in South Korea, 김성한 (2006; 2008) has maintained that evolutionary psychology does not justify sexism. In contrast, 조현진(2015) argues the opposite-evolutionary psychology is sexually biased-through a careful analysis of the massive modularity thesis.

7) Alexander and Hines(2002).

8) Groen et al.(2000).

9) Thornhill and Palmer(2000).

10) Hasunuma and Shin(2019), Lee(2018).

11) Nelson(2017), 264-266.

12) Hume(1739-1740), Moore(1903). For more details about Hume and Moore's conceptions of the naturalistic fallacy, see Wilson et al.(2003), 670-671; Teehan and diCarlo(2004), 34-36. 
that one cannot infer normative conclusions directly from descriptive statements. Since factual descriptions of how the world "is" do not imply any evaluative claim, it is fallacious to deduce normativity ("ought") and values ("good," "bad," etc.) exclusively from descriptions. Appealing to this notion of the naturalistic fallacy, a typical counterargument from evolutionary psychologists unfolds as follows. They claim, first, that what evolutionary psychology does is to provide descriptions of the evolution of a human behavior $\mathrm{x}$ (for example, rape), neither to endorse $\mathrm{x}$ as morally good nor to claim that people ought to do $\mathrm{x}$; and second, that feminist critics erroneously assume that evolutionary psychology's purely factual descriptions imply certain normative conclusions (for example, rape is morally innocent or even desirable).

One such argument is made by Benjamin Winegard and colleagues, who survey undergraduate gender studies textbooks accuse them of committing the naturalistic fallacy. According to Winegard et al., many gender/sex textbooks state as if evolutionary psychology's empirical statements about "what exists" were the normative statement that "what exists is either ipso facto good or morally desirable simply because it exists."13) In response to gender studies' critiques of evolutionary psychology, Winegard and colleagues use a well-known quote by Richard Dawkins: "I am not advocating a morality based on evolution. I am saying how things have evolved. I am not saying how we humans morally ought to behave."14)

Another significant example is Randy Thornhill and Craig Palmer's book titled A Natural History of Rape: Biological Bases of Sexual Coercion. Taking an evolutionary approach to human rape, Thornhill and Palmer explain rape in terms of a natural biological act. The key thesis of the book is that rape is either "an adaptation that was directly favored by selection because it increased male reproductive success by way of increasing mate number"15) or

13) Winegard et al.(2014), 480.

14) Dawkins(1976), 2-3.

15) Thornhill and Palmer(2000), 59. 
"a by-product of other adaptations-including those of men's great interest in and pursuit of impersonal sex-that exist because of their promotion of male reproductive success in contexts other than rape."16) That is, human rape has evolved as an evolutionary adaptation itself, or at least it is a by-product of other evolutionary adaptations. (The following sections will delve into Thornhill and Palmer's argument more thoroughly.)

Unsurprisingly, the evolutionary account of rape has provoked much criticism from feminist researchers. Many feminist philosophers of science as well as social scientists have aptly pointed out that, although Thornhill and Palmer would not personally endorse rape, their explanation of the evolutionary roots of rape could make rape look "less bad" or "less immoral."17) For example, Peggy Reeves Sanday notes:

I suggest that by seeing rape mainly as a product of human evolution, the evolutionary argument provides scientific support for the well-known popular belief in U.S. society that "boys will be boys" and "girls ask for it." Although Thornhill and Palmer neither condone rape nor see it as good socially or psychologically, their arguments are nonetheless part of the same cultural selection process that legitimizes a discourse that looks the other way when young males rape on the grounds that they are, after all, only human.18)

That is, the evolutionary account contributes to perpetuating the culture that condones rape by suggesting that rape is a "natural" human male behavior.

Thornhill and Palmer invoke the concept of the naturalistic fallacy to answer this type of criticism. According to the two authors, the underlying assumption of feminist critiques is that "if rape was favored by "natural" selection, it must be "natural" and hence good or at least excusable."19) They

16) Thornhill and Palmer(2000), 63.

17) Most notably, the edited volume Evolution, Gender, and Rape (Travis ed. 2003) contains seventeen critiques of Thornhill and Palmer's work. For recent critiques, see Alcoff(2018), Weaver and Fehr(2017), and Weaver(2019).

18) Sanday(2003), 342-343. 
mention the naturalistic fallacy several times in their book, which include the following:

A trait that increases [reproductive success] is "good" in terms of natural selection even though one might consider it undesirable in moral terms. There is no connection here between what is biological or naturally selected and what is morally right or wrong. To assume a connection is to commit what is called the naturalistic fallacy.20)

Would that [human rape was an adaptation] imply that rape was "natural" and therefore good? [...] We think not. To think otherwise is to fall prey to the naturalistic fallacy. ${ }^{21)}$

Here, Thornhill and Palmer's argument against feminist critiques-along with other evolutionary psychologists' rebuttal to those critiques-has the following structure:

- Premise 1. Accounts of human behavior that evolutionary psychology presents are descriptions of natural facts. For example, Thornhill and Palmer's conclusion that "rape is naturally selected" is a factual/ descriptive statement.

- Premise 2. It is erroneous to deduce evaluative/normative statements directly from factual/descriptive statements (i.e., the naturalistic fallacy).

- Premise 3. Feminist critiques of evolutionary psychology argue that evolutionary accounts on gender, sex, and sexuality has problematic implications. According to their view, the statement that "rape is naturally selected" implies evaluative/normative statements such as "rape is good" or "rape is not ethically wrong." That is, they deduce the latter statements from the former.

- Conclusion. Therefore, feminist critiques of evolutionary psychology commit the naturalistic fallacy.

19) Thornhill and Palmer(2000), 121.

20) Thornhill and Palmer(2000), 5-6.

21) Thornhill and Palmer(2000), 84. 
This paper seeks to refute the accusation of the naturalistic fallacy against feminist critiques of evolutionary psychology, by using Thornhill and Palmer's work as a paradigmatic case. I will demonstrate that Premise 1 is false, and therefore, the Conclusion does not follow. In order for evolutionary psychologists like Thornhill and Palmer to successfully charge their critics with the naturalistic fallacy, their evolutionary accounts of human behavior must be factual/descriptive statements. However, Thornhill and Palmer's account of rape is not a pure description of natural facts. Their research conclusion that rape is an evolved mechanism is, as I will demonstrate in the next section, permeated with and founded on their biased value judgments.22) Because their evolutionary account is not entirely descriptive, to raise ethical and social concerns about it (that is, to derive normative implications from their research conclusion) is not a case of the naturalistic fallacy.

Before proceeding further, it is important to clarify what exactly is fallacious about the naturalistic fallacy. On the one hand, when evolutionary psychologists use the term naturalistic fallacy, it typically refers to the misbelief that something is (a) "ethically acceptable simply because it is natural."23) For example, Thornhill and Palmer claim that rape being a natural biological behavior does not legitimize it. On the other, the naturalistic fallacy

22) My argument draws on Nils-Frederic Wagner and Georg Northoff's discussion of the naturalistic fallacy (or the lack of thereof) in neuroethics. According to them, neuroethical arguments often have what they refer to as "semi-normative claims"-i.e., claims that are not entirely empirical but rather have some question-begging normative assumptions-as extra premises, in order to avoid inferring a normative conclusion directly from an empirical premise. When such claims are added to an empirical statement, it helps to deduce a neuroethical conclusion that justifies the smuggled normative assumption (Wagner and Northoff 2015, 220-227). I argue that Thornhill and Palmer's "biased value judgments" play a similar but more active role than semi-normative claims: Thornhill and Palmer's biased judgments are not merely added to, but rather actively shape and ground, their theory of rape.

23) Wilson et al.(2003), 672. 
is often used interchangeably with (b) the fact vs. value distinction, which does not allow "deriving value statements from purely factual statements." 24$)$ In this sense, the naturalistic fallacy indicates that, unless there is an additional premise, it is illogical to deduce value only from a value-free observation of natural facts. ${ }^{25}$ )

To be sure, (a) and (b) are closely related to and not clearly distinguished from each other. Here I make a conceptual distinction between the two types of the naturalistic fallacy in order to consider a possible rebuttal from evolutionary psychologists. They might claim that my critique of evolutionary psychology relies on equivocation, switching the meaning of the naturalistic fallacy from (a) to (b). That is, if the only reason that I argue feminist critiques are not committing the naturalistic fallacy is because evolutionary psychology's observations are not purely factual, evolutionary psychologists might respond: Sure, we acknowledge that, but that's not the problem we mean when we speak of the naturalistic fallacy. Thanks to the development of philosophy of science discussions, ${ }^{26)}$ there has been a growing recognition in science communities that no research is perfectly value-neutral. The selection of research topic, method, and literature requires some evaluative judgments (e.g., why certain topic is "better" than others), and researchers are always "situated" in socio-historical context whose values affect and shape their perceptions. In this regard, Thornhill and Palmer might say that they admit the inevitable value-ladenness of their observation, and yet, it is still fallacious to infer rape being morally good from their observation that rape is naturally selected.27)

What I mean by saying that Premise 1 is false-that is, by saying that evolutionary accounts of human behavior are not purely factual-is not just that evolutionary psychology research involves some value judgments (about,

24) Teehan and DiCarlo(2004), 32-33.

25) Teehan and DiCarlo(2004), 34.

26) See, for example, Hanson(1965), Haraway(1988), and Harding(1992).

27) I thank an anonymous reviewer for their insights on this discussion. 
e.g., research topic selection) that are unavoidable for all kinds of scientific research. I argue that evolutionary psychology's approach to gendered behavior is produced on the basis of and reproduces biased value judgments, not just some inevitable value judgments. By "biased" value judgments, I refer to those that are hardly justifiable in terms of epistemology and/or ethics. Admittedly, there is no clear standard for determining whether a value judgment is justifiable or not. Nevertheless, there seems to be enough ground to say that the evolutionary account of rape is grounded on some epistemically and ethically "suspicious" choices, which disregard other existing and possible explanations, as well as reflect and reproduce (rather than challenge) hetero-cis-sexist biases. More specifically, Thornhill and Palmer make at least three types of biased move28) in their book. The following sections will elaborate on each of the three moves: They overemphasize the importance of adaptation in evolutionary process and methodology (section 2.1), dismiss cultural and social context of rape behaviors (section 2.2), and adopt binary frameworks of gender, sex, and sexuality when interpreting empirical data (section 2.3). The point is that, without these three biased choices, Thornhill and Palmer's evolutionary account cannot hold. Insofar as their account of rape is pervaded with and inseparable from the biased evaluative judgments, it is not a factual description of rape. And insofar as their account of rape is not a pure description, the charge of the naturalistic fallacy against their feminist critics is untenable, since it is not the case that the critics derive normative conclusions from a description.

28) In addition to "evaluative statements," this paper will use generic terms such as "evaluative moves/choices/judgments," whose meaning is not restricted to propositional statements but also encompasses non-propositional attitudes accompanied by everyday bias. 


\section{Biased Value Judgments that Ground Evolutionary Psychology of Rape}

\subsection{Two Types of Adaptationism: Strong Pan-Selectionism and}

Strong Heuristic Adaptationism

According to Thornhill and Palmer, there are only two reasonable accounts of rape: rape has evolved as an adaptation or as a by-product of adaptations. That is, rape is a trait formed either directly or indirectly by selective pressures; there are no other likely candidates for evolutionary causes of rape than these two.29) Elisabeth Lloyd, a philosopher of biology, points out that this assertion is hardly justified in modern evolutionary theory. Adaptation and the effect of adaptation, as Lloyd notes, are not exhaustive options for evolutionary explanations of a trait.30) Thornhill and Palmer's pursuit to "explain all interesting traits in terms of selective forces alone" 31 ) falls under the approach called adaptationism that has been criticized by philosophers of biology.

In this section, I will look more closely into what adaptationism is and demonstrate that Thornhill and Palmer's account is grounded on their methodologically biased choice of adaptationism. I employ the taxonomy of adaptionism put together by Tim Lewens. Lewens distinguishes four kinds of adaptationism and divides them into seven sub-types.32) I argue that, among them, two forms of adaptationism are particularly at work in Thornhill and Palmer's theory of rape: (i) strong pan-selectionism and (ii) strong heuristic adaptationism.

Pan-selectionism refers to the belief that "natural selection is the most significant of the evolutionary forces that act on populations." 33 ) Evolutionary

29) Thornhill and Palmer(2000), 11.

30) Lloyd(2003), 244-245.

31) Lloyd(2003), 240.

32) Lewens(2009). 
biologists who endorse pan-selectionism value selection as the most important evolutionary force, while thinking of other evolutionary forces as unimportant. ${ }^{34)}$ Thornhill and Palmer, in particular, hold a strong version of pan-selectionism that views selection as the most important and the only cause of evolution. They note that there are four evolutionary causes of traits-selection, drift, gene flow, and mutation-but quickly disregard the latter three as unlikely.35) It is this overemphasis on selection that enables the two authors to reach the conclusion that rape behavior must be directly or indirectly favored by selection, that is, rape must be an adaptation or a by-product of adaptations.

Both Lloyd and Lewens effectively show that pan-selectionism is scientifically incorrect.36) Although I agree wholeheartedly with them, the purpose of the present article is not to scientifically debunk strong pan-selectionism and other forms of adaptationism. This article is concerned with the biased character of adaptionism. To do justice to Thornhill and Palmer, let me suppose that $80 \%$ of traits are directly or indirectly formed by selection, and the rest $20 \%$ of traits can be explained by other evolutionary forces, such as drift, gene flow, and mutation. Then it would be descriptively true that selection is the most common evolutionary force. Yet it does not follow that selection is the most important force or the only force that matters in explaining causes of a trait. The belief that the most common cause is the solely important one, and that less common causes can be dismissed as unimportant and unworthy of study, is an evaluative claim biased in favor of commonness.

Heuristic (or methodological) adaptationism, especially the strong version of it, is another form of adaptationism that underlies Thornhill and Palmer's account. Unlike pan-selectionism, heuristic adaptationism does not present a hypothesis about what is the most significant factor in evolutionary process.

33) Lewens(2009), 162.

34) Lewens(2009), 163-164.

35) Thornhill and Palmer(2000), 56-59.

36) Lewens(2009), 163-164; Lloyd(1999), 223-226; Lloyd(2003). 239-247. 
Instead, it asserts that adaptation provides the best methodology to investigate evolutionary process. Lewens distinguishes between weak and strong heuristic adaptationisms. ${ }^{37)}$ While the weak version states that we should assume that all traits are adaptations so as to best examine those traits that are actually adaptations, the strong version further contends that "only by beginning to think of traits as adaptations can we uncover their true status, whether they are adaptations or not."38) Thornhill and Palmer employ this strong heuristic adaptationism in their work, when they acknowledge that "not all aspects of living organisms are adaptations" but maintain that it is still "essential to consider the concept of adaptation in all cases of possible phenotypic design, because only then can it be determined if a trait has been designed by natural selection [or not]." "39) Note that this is Thornhill and Palmer's evaluative claim as opposed to a purely descriptive claim. The judgment that the only and the best way to investigate a trait is to regard it as an adaptation, even though it could turn out later that the trait is not an adaptation, is Thornhill and Palmer's overvaluation of the methodological significance of adaptation. This specific biased judgment constructs their theory of rape, according to which rape behavior should be considered as an adaptation or as a by-product of adaptations.

In sum, both types of adaptationism employed by Thornhill and Palmer are not pure descriptions of evolution, but rather are scientifically and methodologically biased approaches reflecting their preference in theorization of evolution. The biasedness of adaptationism indicates that Thornhill and Palmer cannot accuse feminist critics of committing the naturalistic fallacy, that is, the fallacy of deriving normative conclusions from descriptive statements. Thornhill and Palmer's rape-evolution account is biased, in that it holds only because they disproportionately favor adaptation and disregard other ways to explain

37) Lewens(2009), 162, 169-171.

38) Lewens(2009), 162; emphasis added.

39) Thornhill and Palmer(2000), 9-10. 
and examine evolution. Thus, when feminist critics analyze how the evolutionary account of rape being "naturally selected" contributes to the idea of rape being "not morally wrong," they are deriving normative implications from the biased/evaluative claim, not a factual/descriptive one (i.e., their critical analyses do not amount to the naturalistic fallacy).

\subsection{Willful Ignorance of Cultural and Social Context}

There is a tendency in evolutionary psychology to ignore cultural and social contexts of human behavior. This ignorance is not a simple mistake of failing to know, which might be considered epistemically and morally innocent. Rather, it is "willful ignorance," a case of "knowing that [one does] not know, but not caring to know."40) Ignorance in this sense has received considerable attention of social epistemologists since Charles Mills's groundbreaking book The Racial Contract coined the term "epistemology of ignorance." Mills notes that there is an agreement among white people not to care to know about racial oppression facing people of color, and to misinterpret the world as if there is little or no racism. Through this active ignorance, white people maintain the status quo racially unjust world.41)

Carla Fehr, along with many other feminist philosophers of science and epistemologists, analyzes gender/sex injustice issues through the lens of epistemology of ignorance. Fehr examines the comments that the then-president of Harvard University Lawrence Summers made in 2005 on why there were so few women in top science and engineering jobs. Using the so-called "variability hypothesis," which claims that "there is more variation in aptitude among men than among women [and thus] there will be more men than women with extremely high aptitude,"42) Summers attributed the dearth of women in science to biological and genetic factors, while downplaying effects of

40) Tuana(2006), 4-5; cited in Hall(2012), 41.

41) $\operatorname{Mills}(1997)$, 17-19.

42) $\operatorname{Fehr}(2008), 105$. 
socialization and discrimination. ${ }^{43)}$ This exemplifies willful ignorance, in that:

there [was] already a large body of research that provide[d] evidence contrary to Summers's conjectures. [...] What is sexist about Summers's remarks are that they ignore evidence about women's actual abilities, they ignore the need to encourage talented women to remain in the sciences, and they reinforce sexist stereotypes about women in the face of abundant contrary evidence. ${ }^{44)}$

Despite the huge body of knowledge that debunked the variability hypothesis, such as the literature revealing that gender bias and discrimination plays a crucial role in the professional assessment of women in academia, 45 ) Summers chose to not count it as (real) knowledge and to remain ignorant of it.

I argue that a similar mechanism of the epistemology of ignorance operates in evolutionary psychology. Thornhill and Palmer state as if rape were a single, uniform behavior across cultures. Although there is an extensive amount of research on cultural variations in rape, some of which I will discuss below, Thornhill and Palmer choose to not know them. It is this willful ignorance that allows them to explain rape in terms of universal evolution regardless of cultural differences. To put it more generally, an evolutionary account of a human behavior can assert its cross-cultural/universal validity only when the researcher does not care to know about social science and humanities research on the significant role of socio-cultural factors in shaping and explaining the behavior. Here, Thornhill and Palmer make a biased value judgment to exclude the knowledge on social/cultural contexts of rape from the realm of (real) knowledge, just as Summers did.

In particular, the two authors use a strategy to dismiss feminist accounts of rape as "ideology," the opposite of the true "science" that they are doing.46)

43) $\operatorname{Fehr}(2008)$, 109-110.

44) Fehr(2008), 113.

45) See Fehr(2008), 111 for more details. Recent research includes MacNell et al.(2015) and Mitchell and Martin(2018). 
For example, they cite Peggy Sanday's work with the Minangkabau of West Sumatra, Indonesia as an example of feminist accounts of rape, which shows that the Minangkabau ethos of mutual respect between the sexes contributes to making their society virtually rape-free.47) However, instead of representing Sanday's research fairly and taking the existence and analysis of rape-free society seriously, Thornhill and Palmer do not care to know about it. They assert that "some frequency of rape is typical of Homo sapiens [and] there is no evidence of a truly rape-free society"48) That is, for Thornhill and Palmer, research like Sanday's does not amount to "evidence." How so? Because it is mere political ideology, not real scientific knowledge. This way, Thornhill and Palmer do not need to know or engage in the "social science study of rape" (they lump a variety of analyses from feminist theories and social sciences into the single category). ${ }^{49}$ )

To be sure, Thornhill and Palmer apparently refuse genetic determinism. That a behavior is genetically determined indicates that it is "rigidly fixed by genes and hence not alterable except by changing those genes." 50 ) As noted in the following, the two authors deny the deterministic view:

[The absence of evidence of a truly rape-free society] does not mean, of course, that rape is a genetically determined act unaffected by learning and culture. It means only that human males in all societies so far examined in the ethnographic record possess genes that can lead, by way of ontogeny, to raping behavior when the necessary environmental factors are present, and that the necessary environmental factors are sometimes present in all societies

46) This strategy is known as the "Galileo Defense," which basically says: "I am telling the Truth and doing excellent science, but because of ideology and ignorance, I am being persecuted." (Lloyd 2003, 235).

47) Sanday(1981; 2003).

48) Thornhill and Palmer(2000), 142.

49) They write, "intertwining of explanations of rape and political ideology has caused the naturalistic fallacy to a truly impressive role in the social science study of rape" (Thornhill and Palmer 2000, 125).

50) Thornhill and Palmer(200), 110. 
studied to date. ${ }^{51)}$

Nevertheless, this passage shows that Thornhill and Palmer do not give actual weight on cultural factors. Although they acknowledge that rape behavior might be influenced by cultural context, they do not take cultural variation of rape seriously. Rather, they seem to be more concerned with the uniformity of rape across cultures. The passage above claims that genes that can lead to rape as well as the environmental factors necessary for rape are present in all societies. An underlying assumption here is that a single thing called "rape" exists (or, at least, can exist) across societies.

This assumption, however, has been refuted by feminist philosophers and social scientists. As Rachel Martin points out, rape is "a behavior whose very existence depends on the intentions and reactions of at least two complex social beings in some particular context."52) What act amounts to rape is closely linked to intentions, such as those to rape, to resist, and to consent to sex. But intentions cannot be identified without considering complex contexts in which the social beings are situated, for instance, "what are the social norms governing sexuality in this place and time, what are the rights of women, the obligations of men, what is proper conduct for women during sex, how is force exerted or resisted." 53 ) Since these contexts vary profoundly according to culture and society, rape cannot exist as a single, uniform behavior.

To illustrate cultural variation, Martin cites the traditional model of East Asian marriage, according to which marriage was a contract between two families that gave the husband sexual access to his wife. There was no room in this model for "the consent of the wife," or more precisely, "the wife's right not to consent." It would be misleading to use the (contemporary) Western notion of consent to distinguish between what is marital rape and

51) Thornhill and Palmer(2001). 142; emphasis added.

52) $\operatorname{Martin}(2003), 369$.

53) $\operatorname{Martin}(2003), 372$. 
what is not, as the cultural contexts underlying this model might always regard the wife as having "consented to sex" by getting married. ${ }^{54)}$ The meaning of rape not only varies across cultures, but it changes greatly over time within a culture. For example, rape had been regarded mainly as "property theft" until the early modern period of Western history, in which the wife had been considered as the patriarchal property.55)

In short, Thornhill and Palmer's research is grounded on their evaluative choice to stay ignorant of socio-cultural context surrounding rape. It is this willful ignorance, which is an epistemically and morally suspicious choice, that enables Thornhill and Palmer's evolutionary approach to rape. Given that it cannot hold up without willful ignorance, their research conclusion that "rape is a cross-cultural, universal behavior that is naturally selected" is a biased evaluative claim, not a purely factual claim. Therefore, feminist critics of their evolutionary accounts of rape do not commit the naturalistic fallacy of inferring value/ethical from fact/natural. They are inferring value (i.e., problematic social, ethical implications) from value (i.e., biased evaluative choice to dismiss sociocultural context of rape), not from fact.

\subsection{Binary Understanding of Gender and Sex}

So far, this paper has discussed as to how Thornhill and Palmer's reduction of the entire rape behavior to adaptation (section 2.1) with no attention to sociocultural factors (section 2.2) is a biased evaluative move, which makes their evolutionary account of rape based thereon is a biased evaluative statement, not a purely factual one as they claim it to be. The current section focuses on the authors' projection of two discrete sets of images of human males and females. Thornhill and Palmer's account is grounded on a binary understanding of gender/sex ${ }^{56)}$ that reflects androcentric, hetero- and cis-normative

54) $\operatorname{Martin}(2003)$, 368-369.

55) Martin(2003), 372-373.

56) In this paper I use the term "gender/sex" to refer to both "gender" and 
biases in society.

Explaining rape in terms of adaptation, Thornhill and Palmer take male reproductive success to be the driving force of adaptation. That is, rape is an adaptation favored by selection "because it increased male reproductive success"57) or a by-product of other adaptations favored by selection "because

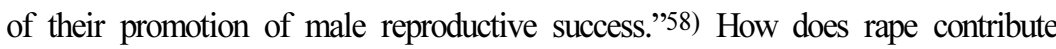
to male reproductive success? The following scenarios, according to Thornhill and Palmer, illustrate the ways in which rape offers reproductive benefits:

$[R]$ apists are predicted to deliver large ejaculates because rape would consistently have been associated with high sperm competition in human evolutionary history. The woman's resistance during rape is expected to be perceived by the rapist as indicating that she has an investing consensual mate. Also, rape in warfare is expected to have often involved multiple men inseminating a victim over a short period of time, with men often copulating in the presence of other men and placing their sperm in competition with the sperm of others. ${ }^{59)}$

Raping an unwilling pair-bonded mate may be a male tactic of sperm competition. A woman's sexual unreceptivity may suggest to her partner that she is having consensual intercourse with another male. Because men associate sexual unwillingness and resistance in their long-term mates with infidelity, sexual unwillingness may lead to sexual jealousy, and sometimes to rape as a sperm-competition tactic. ${ }^{60)}$

"sex." Gender/sex is an umbrella term that Sari van Anders coined to note that gender (social) and sex (biological) cannot be easily disentangled (van Anders 2015, 1181). Multiple research programs on the impacts of gender, sex, and their interactions with other social variables on the subject phenomena, including Harvard's recent project on COVID-19 and gender/sex disparities, use this term gender/sex "in order to emphasize the continuous and dynamic relationships between biology, behavior, and social structures" (Danielsen and Noll 2020).

57) Thornhill and Palmer(2000), 59.

58) Thornhill and Palmer(2000), 63.

59) Thornhill and Palmer(2000), 74. 
As these rape scenarios show, Thornhill and Palmer's evolutionary psychology depicts the male as a being who is primarily, if not exclusively, driven by the interest in reproductive success. In contrast, the female is depicted only as a means of reproduction. Males are always represented as sperm producers, and females are represented as receivers of sperm. These are the only two "normal"-and in this sense, "right"-sex roles that Thornhill and Palmer's theory designates to males and females respectively. The male agent whose behavior is not driven by the interest in reproductive success and the female agent who is in the age of fertility but does not perform the role of means of reproduction are not allowed in Thornhill and Palmer's theory. Relatedly, the authors leave no room for human beings who do not conform to such "correct" male vs. female sex roles defined in terms of reproduction. As Ann Caroline Danielsen and Nicole Noll aptly note, this kind of binary framework exhibits and naturalizes cis- and hetero-centric conceptualizations of gender/sex. "This perpetuates the invisibility of intersex, trans, non-binary, genderqueer, and other individuals who live their lives beyond the binary."'61)

Thornhill and Palmer's dichotomous framework is closely related to other assumptions that they make on gender/sex and rape. Discussing to what extent the evolutionary account of rape constitutes "bad science," Michael Kimmel notes that Thornhill and Palmer make two "bad assumptions": first, that rape is only about sex, and second, that sex is only about reproduction. Neither of these is supported by empirical evidence. Counterexamples include prison rape and gang rape, which are not only about sex but also about power and domination, ${ }^{62}$ ) and the rape of men by other men, of prepubescent children, and of postmenopausal women, which are not intercourse with fertile women and thus undermine the account of rape as a biological imperative for reproduction. ${ }^{63)}$

60) Thornhill and Palmer(2000), 77.

61) Danielsen and Noll(2020).

62) $\mathrm{Kimmel}(2003)$, 224-225.

63) Lloyd(2003), 240. 
A possible counterargument from Thornhill and Palmer is that evolutionary psychology does not explain all current human behaviors as adaptations. That is, they might claim that rape was evolved as an adaptive program in ancestral environments to increase reproductive success, but there is no guarantee that it is so in modern environments. ${ }^{64)}$

In addition, it is also possible for evolutionary psychologists to argue for a modest, revised evolutionary account, namely, that rape is mostly (though not exclusively) about sex and sex is mostly about reproduction. For example, Thornhill and Palmer might contend that human males in general are driven by the interest in reproductive success and females in general are choosier than their male counterparts65) and suggest empirical evidence supporting these predictions. In this case, I would argue that the problem is not with empirical evidence per se but also with the way it is interpreted: Thornhill and Palmer presuppose the binary between promiscuous male vs. the choosy female and interpret evidence in a way that it fits the binary, while dismissing variations. They rely on the dominant interpretive mechanism in biology that Helen Longino argues contrasts with ontological heterogeneity. According to this anti-heterogeneity mechanism, "entities that are not members of the privileged class [are treated] either as epiphenomena [...] or as variants whose deviations from the standard can be disregarded."'66) Similarly, Letitia Meynell notes:

If one believes one has evidence for two different modules that underlie differences in sex behavior and are part of jointly universal human male and female natures, then it is appropriate to treat variance in the behavior itself as noise. [...] The simplistic evolutionary assumptions (especially modularity) direct the interpretation of the results toward finding [two distinct forms of

64) Tooby and Cosmides(2005), 17.

65) Following Darwinian sexual selection, Thornhill and Palmer assume that "males will be less discriminating about and more eager to copulate with females than vice-versa," and that this difference between males and females will account for the root of human rape (Thornhill and Palmer 2000, 38).

66) Longino(1995), 393. 
behavior], actively suppressing as uninteresting the overlap between the sexes and the variation among individuals within sex groups.67)

This mechanism of suppressing diversity operates in Thornhill and Palmer's account of rape. Focusing solely on the binary sex roles that they believe to be "correct," Thornhill and Palmer regard the existence of males who are not sex-driven and that of intersex, trans, and queer people merely as "noise" or "epiphenomenon." The judgment that the dichotomous sex roles deserves an almost exclusive focus of research and the variation can be disregarded is an evaluative one, not a factual description of what is. This evaluative judgment reflects the hetero-cis-normative and sexist bias of society, which takes the male vs. female binary for granted and marginalizes non-heterosexual and non-cis individuals. If the variance is taken more seriously, the theory of male sex-driven evolution will not be maintained. In sum, Thornhill and Palmer's evolutionary psychology is grounded on their biased choice of disregarding the variation and diversity in human sex behavior, and thus does not provide a purely empirical description of rape.

\section{Conclusion: Social Implications of Evolutionary Psychology}

This article has critically examined the three types of evaluative move on which Thornhill and Palmer's evolutionary psychology of rape is grounded. First, it employs two forms of adaptationism: strong pan-selectionism and strong heuristic adaptationism. Both forms of adaptationism are not purely descriptive, but instead indicate Thornhill and Palmer's overvaluation of the ontological and methodological importance of adaptation. Second, Thornhill and Palmer assume that rape constitutes a unitary behavior existing in all societies. In so doing, they make a biased epistemic judgment not to bother to know

67) Meynell(2012), 14, 16; see also Roughgarden(2013), 3. 
the extensive contrary evidence suggesting that rape varies according to cultural and social contexts. Lastly, when interpreting biological data, Thornhill and Palmer disregard the diversity of sex, gender, and sexuality and exclusively focus on two discrete sex roles, which reflects cis-hetero-normative bias in society.

In that Thornhill and Palmer's account of rape cannot be sustained without the three biased evaluative moves, it is not a pure description of rape. Therefore, the accusation of the naturalistic fallacy against their feminist critics is unjustified, as it is not the case that feminist critics are deducing social and ethical value statements from descriptive, factual statements. Perhaps the most problematic value judgment operating in evolutionary psychology is the very assumption that the evolutionary explanation of human behavior is irrelevant to social implications-namely, that evolutionary psychology is just doing "science" and the "social consequence is none of its business. Feminist philosophers have long argued, as I discussed in this paper, the account of rape being natural perpetuates the rape culture of society that prompts and condones the crime. It is irresponsible for evolutionary psychologists to denigrate all such feminist critiques as the naturalistic fallacy, simply mentioning that they have no intent to legitimize rape. I conclude by quoting Kim Hall, who notes that this assumption itself shows evolutionary psychology's willful ignorance:

Biological explanations of human nature have historically advantaged those who approximate bodily norms and those with economic, gender, race, and sexual privilege. Why should we assume that science is now free of this history? It seems the only way to believe that such mistakes are no longer possible is to ignore the fact that science is a social practice, influenced by culture and history. ${ }^{68)}$

68) Hall(2012), 42. 


\section{References}

김성한(2006). 「강간에 대한 진화심리학의 설명 비판은 타당한가?」.

『철학』89호. 한국철학회, 141-169.

(2008). 「진화심리학이 성매매에 시사하는 바는 무엇인가?」.

『철학연구』82집. 철학연구회. 97-117.

김요한(2019). 「진화심리학의 도덕 개념에 대한 비판적 연구」. 『동서

철학연구』91호. 한국동서철학회. 353-376.

윤보석(2010). 「구현주의와 진화심리학」. 철학연구』89집. 철학연구회.

153-173.

장대익•이민섭(2018). 「역겨움의 도덕적 지위에 관하여」. 『철학연구』

122집. 철학연구회. 51-84.

조현진(2015). 「진화심리학의 성적 편향성과 그 정치철학적 함축 비

판」『한국여성철학』24권. 한국여성철학회. 113-148.

(2019). 「진화 심리학의 도전-사기꾼 탐지 모듈과 자연주의적인

오류를 중심으로-」. 철학논집』57집. 서강대학교 철학연구소.

31-59.

천현득(2009). 「진화심리학의 아슬아슬한 줄타기: 대량 모듈성에 대한 재고」『철학연구』87집. 철학연구회. 189-225.

Alcoff, L. M.(2018). Rape and Resistance. Cambridge: Polity Press.

Alexander, G. \& Hines, M.(2002). "Sex Differences in Response to Children's Toys in Nonhuman Primates (Cercopithecus aethiops sabaeus)." Evolution and Human Behavior 23(6), 467-479.

Barrett, H. C.(2015). The Shape of Thought: How Mental Adaptations Evolve. Oxford: Oxford University Press.

Buller, D.(2005). Adapting Minds: Evolutionary Psychology and the Persistent Quest for Human Nature. Cambridge: MIT Press.

Buss, D. ed.(2005). The Handbook of Evolutionary Psychology. Hoboken: Wiley.

Carruthers, P.(2006). The Architecture of the Mind. Oxford: 
Clarendon Press.

Cosmides, L.(1989). "The Logic of Social Exchange: Has Natural Selection Shaped How Humans Reason? Studies with the Wason Selection Task." Cognition 31, 187-276.

Cosmides, L. \& Tooby, J.(2005). "Neurocognitive Adaptations Designed for Social Exchange." In Buss(2005), 584-627.

Crasnow, S. \& Intemann, K. eds.(2021), The Routledge Handbook of Feminist Philosophy of Science. New York and London: Routledge.

Danielsen, A. C. \& Noll, N. E.(2020). "Communicating about COVID-19 and Sex Disparities: A Guide for Media, Scientists, Public Health Officials, and Educators." GenderSci Blog, Harvard University, June 24. https://www.genderscilab.org/ blog/covid-communication.

Dawkins, R.(1976). The Selfish Gene. Oxford: Oxford University Press.

Fehr, C.(2008). "Are Smart Men Smarter Than Smart Women? The Epistemology of Ignorance, Women, and the Production of Knowledge.” In May(2008), 102-116.

(2012). "Feminist Engagement with Evolutionary Psychology." Hypatia 27(1), 50-72.

Fodor, J. A.(1983). The Modularity of Mind. Cambridge: MIT Press.

Garry, A., Khader, S. J., \& Stone, A. eds.(2017), The Routledge Companion to Feminist Philosophy. London and New York: Routledge.

Groen, G., Wunderlich, A. P., Spitzer, M., Tomczak, R., \& Riepe, M. W.(2000), "Brain Activation during Human Navigation: Gender Different Neural Networks as Substrate of Performance." Nature Neuroscience 3(4), 404-408. 
Hall, K. Q.(2012). “Not Much to Praise in Such Seeking and Finding': Evolutionary Psychology, the Biological Turn in the Humanities, and the Epistemology of Ignorance." Hypatia 27(1), 28-49.

Hanson, N. R.(1965). Patterns of Discovery: An Inquiry into the Conceptual Foundations of Science. Cambridge: Cambridge University Press.

Haraway, D.(1988). "Situated Knowledges: The Science Question in Feminism and the Privilege of Partial Perspective." Feminist Studies 14(3), 575-599.

Harding, Sandra. 1992. "Rethinking Standpoint Epistemology: What Is 'Strong Objectivity?'." The Centennial Review 36(3), 437-470. Hasunuma, L. \& Shin, K.(2019). "\#MeToo in Japan and South Korea: \#WeToo, \#WithYou." Journal of Women, Politics \& Policy 40(1), 97-111.

Heams, T., Huneman, P., Lecointre, G., \& Silberstein, M. eds.(2015), Handbook of Evolutionary Thinking in the Sciences. Dordrecht: Springer.

Hume, D.(1739-1740). 2000. A Treatise of Human Nature. D. F. Norton and M. J. Norton eds. Oxford: Oxford University Press. Huneman, P. \& Machery, E.(2015). "Evolutionary Psychology: Issues, Results, Debates." In Heams et al.(2015), 647-657.

Kimmel, M.(2003). “An Unnatural History of Rape.” In Travis (2003), 221-233.

Lee, S.(2018). “'Our Lives Are Not Your Porn': South Korean Women Cry Out Against Spycam Porn'.” The Korea Times, August 7. https://www.koreatimes.co.kr/www/nation/2018/08/ 281_253388.html.

Lewens, T.(2009). "Seven Types of Adaptationism." Biology and Philosophy 24(2), 161-182. 
Lloyd, E. A.(1999). "Evolutionary Psychology: The Burdens of Proof." Biology and Philosophy 14(2), 211-233.

(2003). "Violence against Science: Rape and Evolution." In Travis(2003), 235-262.

Longino, H. E.(1995). "Gender, Politics, and the Theoretical Virtues." Synthese 104(3), 383-397.

MacNell, L., Driscoll, A., \& Hunt, A. N.(2015). "What's in a Name: Exposing Gender Bias in Student Ratings of Teaching." Innovative Higher Education 40, 291-303.

Martin, E.(2003). "What Is 'Rape' - Toward a Historical Ethnographic Approach." In Travis(2003), 363-382.

May, A. M. ed.(2008). The 'Woman Question' and Higher Education: Perspectives on Gender and Knowledge Production in America. Cheltenham and Northampton: Edward Elgar Publishing.

Meyers, D. T. ed.(2012). FEAST Cluster on Feminist Critiques of Evolutionary Psychology. Hypatia 27(1).

Meynell, L.(2012). "Evolutionary Psychology, Ethology, and Essentialism (Because What They Don't Know Can Hurt Us)." Hypatia 27(1), 3-27. (2021). "What's Wrong with (Narrow) Evolutionary Psychology." In Crasnow \& Intemann(2021), 303-315.

Mills, C. W.(1997). The Racial Contract. Ithaca: Cornell University Press.

Mitchell, K. \& Martin, J.(2018). "Gender Bias in Student Evaluations." PS: Political Science \& Politics 51(3), 648-652.

Moore, G. E.(1903). Principia Ethica. Cambridge: Cambridge University Press.

Nelson, L. H.(2017). "Evolutionary Psychology, Feminist Critiques Thereof, and the Naturalistic Fallacy." In Ruse \& Richards 
(2017), 257-272.

O'Donavan, M.(2013). "Feminism, Disability, and Evolutionary

Psychology: What's Missing?" Disability Studies Quarterly 33(4).

Richardson, R.(2007). Evolutionary Psychology as Maladapted Psychology. Cambridge: MIT Press.

Roughgarden, J.(2013). Evolution's Rainbow: Diversity, Gender, and Sexuality in Nature and People. Berkeley and Los Angeles: University of California Press.

Ruse, M. \& Richards, R. J. eds.(2017). The Cambridge Handbook of Evolutionary Ethics. Cambridge: Cambridge University Press.

Sanday, P. R.(1981). "The Socio-Cultural Context of Rape: A Cross-Cultural Study." Journal of Social Issues 37(4), 5-27.

Sanday, P. R.(2003). "Rape-Free versus Rape-Prone: How Culture Makes a Difference." In Travis(2003), 337-361.

Teehan, J. \& diCarlo, C.(2004). "On the Naturalistic Fallacy: A Conceptual Basis for Evolutionary Ethics." Evolutionary Psychology 2(1), 32-46.

Thornhill, R. \& Palmer, C. T.(2000). A Natural History of Rape: Biological Bases of Sexual Coercion. Cambridge: MIT Press.

Tooby, J. \& Cosmides, L.(2005). "Conceptual Foundations of Evolutionary Psychology.” In Buss(2005), 5-67.

Travis, C. B. ed.(2003). Evolution, Gender, and Rape. Cambridge: MIT Press.

Tuana, N.(2006). "The Speculum of Ignorance: The Women's Health Movement and Epistemologies of Ignorance." Hypatia 21(3), 1-19.

van Anders, S. M.(2015). "Beyond Sexual Orientation: Integrating Gender/Sex and Diverse Sexualities via Sexual Configurations Theory." Archives of Sexual Behavior 44(5), 1177-1213. 
Wagner, N.-F. \& Northoff, G.(2015). “A Fallacious Jar? The Peculiar Relation between Descriptive Premises and Normative Conclusions in Neuroethics." Theoretical Medicine and Bioethics 36(3), 215-235.

Weaver, S.(2019). "The Harms of Ignoring the Social Nature of Science." Synthese 196, 355-375.

Weaver, S. \& Fehr, C.(2017), "Values, Practices, and Metaphysical Assumptions in the Biological Sciences." In Garry et al.(2017), 314-327.

Wilson, D. S., Dietrich, E., \& Clark, A. B.(2003). "On the Inappropriate Use of the Naturalistic Fallacy in Evolutionary Psychology." Biology and Philosophy 18(5), 669-681.

Winegard, B. M., Winegard, B. M., \& Deaner, R. O.(2014). "Misrepresentations of Evolutionary Psychology in Sex and Gender Textbooks." Evolutionary Psychology 12(3), 474-508. 
<국문요약>

\title{
진화심리학, 강간, 자연주의적 오류
}

\author{
공 유 진 \\ (오리건주립대학교 조교수)
}

진화심리학에 대한 페미니즘적 비판은 종종 자연주의적 오류를 저지른 다는 반론에 직면한다. 즉, 진화심리학의 기술적인 설명으로부터 규범적 인 결론을 이끌어내는 오류를 저지른다는 것이다. 본 논문의 목적은 이 러한 자연주의적 오류 논증을 논박하는 데 있다. 이를 위해 나는 어떻게 진화심리학의 설명이 전적으로 기술적인 것이 아니라 편향적인 가치판단 에 기반하고 있는지 분석할 것이다. 톤힐과 파머의 저작『강간의 자연사』 를 중심으로, 나는 강간에 대한 진화심리학적 설명이 (1) 진화에 대한 적 응주의적 접근, (2) 문화적, 사회적 맥락에 대한 의도적인 무지, (3) 성에 대한 이분법적 이해라는 세 가지 편향성에 의존하고 있음을 입증할 것이 다. 이와 같은 편향적 가치판단에 의존하지 않고서는 톤힐과 파머의 진 화심리학적 설명이 성립하지 않는다는 점을 고려할 때, 톤힐과 파머가 강간에 대해 전적으로 사실적, 기술적으로 설명하고 있다고 보기 어렵다. 따라서, 그들의 진화심리학 이론에 대한 페미니즘적 비판은 가치판단이 들어가지 않은 기술적 설명으로부터 규범적 결론을 이끌어내는 것이 아 니므로, 자연주의적 오류를 저지르는 것이 아니다.

주제분류: 여성철학, 과학철학, 사회철학

주 요 어: 진화심리학, 강간, 자연주의적 오류, 편향적 가치판단, 적응 주의, 의도적인 무지, 사회문화적 맥락, 젠더 이분법/성 이 분법

접수일: 2021년 08월 15일/ 심사일: 2021년 08월 24일 09월 25일/ 게재확정일: 2021년 09월 18일

Evolutionary Psychology, Rape, and the Naturalistic Fallacy / Kong, Youjin || 93 